\title{
THE CHANGING FORESTS OF CENTRAL OKLAHOMA: A LOOK AT THE COMPOSITION OF THE CROSS TIMBERS PRIOR TO EURO- AMERICAN SETTLEMENT, IN THE 1950S, AND TODAY
}

\author{
Richard E. Thomas \\ Department of Geography \\ and Environmental Sustainability \\ University of Oklahoma \\ Norman, OK 73019
}

\author{
Bruce W. Hoagland \\ Department of Geography \\ and Environmental Sustainability, \\ Oklahoma Natural Heritage Inventory \\ University of Oklahoma \\ Norman, OK 73019
}

Keywords: Surveys, historical ecology, mesophication, cross timbers, fire

\begin{abstract}
Prior to Euro-American settlement, the Cross Timbers of the Southern Plains marked the edge of "civilization," beyond which lay a prairie ecosystem ruled primarily by Plains Indian tribes. War, trade, and pasture for cattle brought an increased Euro-American presence by the middle of the $19^{\text {th }}$ century. In the early 1870s a large portion of what was to become the state of Oklahoma was surveyed by the General Land Office (GLO). Although these surveys were not conducted for ecological purposes, they have provided information on pre-settlement vegetation that has been invaluable for researchers seeking to reconstruct the historical landscape. Perhaps the most beneficial information for historical ecologists and biogeographers comes from data on bearing trees recorded by GLO surveyors, which have given present-day researchers a good idea of the species composition of Cross Timbers forests during this time. When compared to modern studies of the Cross Timbers, it documents a change in species composition over time, believed to be the result of fire suppression and perhaps the beginning of a wetter climate cycle. In central Oklahoma, this has meant a shift from forests dominated by Quercus marilandica and Quercus stellata (with the former being more abundant) to forests containing an equal abundance of these two species, and an increase in Carya texana, Juniperus virginiana, and other mesophytic and invasive woody species.
\end{abstract}

\section{INTRODUCTION}

\section{Cross Timbers Overview}

The Cross Timbers are a mosaic of riparian forest, woodland, and grassland that extends from southeastern Kansas, through Oklahoma, and into north-central Texas (Dyksterhuis 1948 and 1957, Rice and Penfound 1959, Omernik 1987, Hoagland et al. 1999, Francaviglia 2000; Figure 1). The Cross Timbers encompass an estimated 4.8 million ha in this region (Kuchler 1964). Slightly more than half of the total area (2.5 million ha) is located in Oklahoma, where it comprises a larger area than all other forest types in Oklahoma combined (Duck and
Fletcher 1945; Rice and Penfound 1959; Dwyer and Santelman 1964). As a result, the Cross Timbers are the most studied forest type in Oklahoma.

These studies note the importance of Quercus stellata (post oak) and Q. marilandica (blackjack oak) in Cross Timbers stands. Combined, these two species constitute over $90 \%$ of the canopy cover and $50 \%$ of the basal area (Rice and Penfound 1959, Kennedy 1973). Q. marilandica is the more xeric and fire-tolerant of the two species (Brown and Davis 1973; Givnish 1981; Dooley 1983; Dooley and Collins 1984). Stem density (number of 


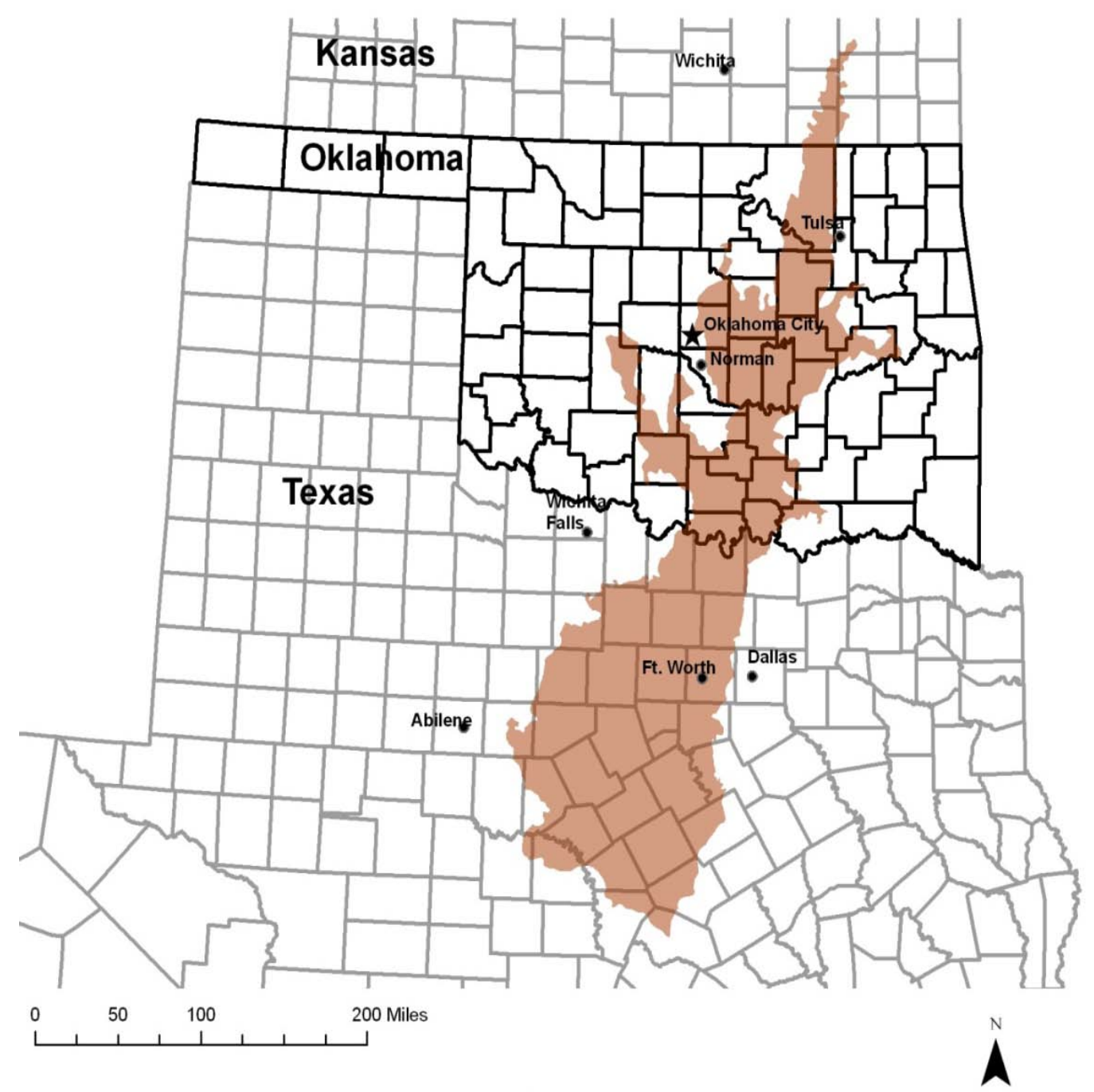

Figure 1 The present-day Cross Timbers (from Omernik, 1987).

stems per unit area) is correlated with slope, aspect, and/or geographic location, but the ratio of $Q$. stellata to $Q$. marilandica has generally ranged from 2:1 to 3:1, (Luckhardt and Barclay 1938, Kennedy 1973). Although stem density of Q. marilandica may surpass Q. stellata on south-facing slopes, $Q$.

marilandica rarely exceeds $30 \mathrm{~cm}$ in diameter and, therefore, basal area values of the two species are roughly equivalent in these instances (Luckhardt and Barclay 1938, Rice and Penfound 1955, 1959).

Woody species of secondary importance include Carya texana (black hickory), Quercus velutina (black oak), and Juniperus virginiana (eastern redcedar) (Coppock et al. 1955, Hale 1955, Rice and Penfound 1955 and 1959, Penfound 1963, Johnson and Risser 1972, Hoagland et al. 1999). The herbaceous understory of the Cross Timbers, which becomes more prevalent in the woodland aspect, is similar to the surrounding prairie (Dyksterhuis, Kuchler 1964 and 1974). Schizachyrium scoparium (little bluestem) dominates most Cross Timbers stands, but Andropogon gerardii (big bluestem) and Sorghastrum nutans (Indiangrass) may be codominant (Kuchler 1964). 


\section{The Changing Cross Timbers}

Three major factors influencing the Cross Timbers region today are urban fringe development, woody plant encroachment, and the "mesophication" of Quercusdominated portions of the Cross Timbers (Coppedge 2001a; Dillard et al. 2006, DeSantis et al. 2010). Urban fringe development (UFD) is currently more geographically ubiquitous in the mainland United States than any other human activity that negatively impacts ecosystems (Czech et al 2000). UFD produces some of the highest local extinction rates and often eliminates most of the native species (Vale and Vale 1976, Luniak 1994, Kowarik 1995, Marzluff 2001, McKinney 2002). Biological communities around these areas are increasingly homogenized (McKinney 2004), producing a "distinct and rapid trajectory of vegetation change towards historically unprecedented and simplified conditions" in some regions (Schulte et al. 2007).

In their study of landscape structure and change within a forest-prairie ecotone, Boren et al. (1997) indicated that increased human activity in densely populated rural areas surrounding urban centers in northern Oklahoma lowered biodiversity, increased homogeneity, and resulted in greater patch fragmentation than a rural landscape with a low-density population. Fragmentation was higher in forested areas than in grasslands in each year of their twenty-four year study, in both low- and high-density areas.

In Oklahoma, the main culprit in woody plant expansion is Juniperus virginiana (eastern redcedar), a native species that has advanced beyond its pre-settlement range and density in the Great Plains and portions of the Cross Timbers (Engle et al. 1997, Coppedge et al. 2001b, Briggs et al. 2002, Horncastle et al. 2005). Encroachment at a rate of 300,000 acres per year in Oklahoma (Drake and Todd 2001) by J. virginiana has many negative consequences, including displacement of native plant species (Engle et al. 1997, Cooper 1998, Coppedge et al. 2002), wildlife species (Engle et al. 1997, Smith 2001, Guthery 2001, Coppedge et al. 2002), a decrease in livestock forage production (Stritzke and Bidwell 1989, Engle and Stritzke 1992, Engle et al. 1997), and a deterioration of water quality (Thurow and Carlson 1994, Cooper 1998).

In a recent study, DeSantis et al. (2010) make the contention that drought and fire suppression are changing the woody species composition of relatively undisturbed portions of the Cross Timbers in Oklahoma. They indicate that woodland portions of the Cross Timbers "appear to be in transition to closed-canopy mesophytic forest stands with less Quercus and more shade-tolerant tree species." In their study, they draw heavily on the work of Nowacki and Abrams (2008), who coined the term "mesophication," which they define as a process "whereby microenvironmental conditions (cool, damp, and shaded conditions; less flammable fuel beds) continually improve for shade-tolerant mesophytic species and deteriorate for shade-intolerant, fire-adapted species." According to the authors, this process is widespread in the forests of North America as a result of fire suppression.

This study sought to characterize Cross Timbers forest and woodland in an urban area in central Oklahoma, focusing specifically on Cross Timbers vegetation that had undergone little visible disturbance (i.e. few invasive species present, trees of varying ages). The area chosen for this was the southeast sector of Oklahoma City, the least developed portion of the city. As a baseline for comparison, General Land Office (GLO) Public Land Survey (PLS) bearing tree data from the 1870 to 1873 survey were analyzed. This analysis relied on results produced in Thomas (2010), which contradict previous analyses of the Cross Timbers in Oklahoma (Shutler and Hoagland 2004, Fagin 2009), but are in line 
with primary historical sources along with past and present research on the woody plant composition of the Oklahoma Cross Timbers.

\section{STUDY AREA}

The southeast sector of Oklahoma City is almost equally divided between Oklahoma and Cleveland counties in central Oklahoma, with a portion falling in Pottawatomie County (Figure 2). Average temperature is around $15^{\circ} \mathrm{C}$, ranging from an average January low of $-3^{\circ} \mathrm{C}$ to an average July high of $34^{\circ} \mathrm{C}$. Average annual precipitation ranges between 91 and $99 \mathrm{~cm}$, and winds from the south and southeast predominate (OCS 2009).

Cross Timbers forest and woodland in the study area is found on the DarnellStephenville soil series, which is made up of moderately deep, well-drained, moderately permeable upland soils with slight to moderate slopes (Fisher and Chelf 1969).

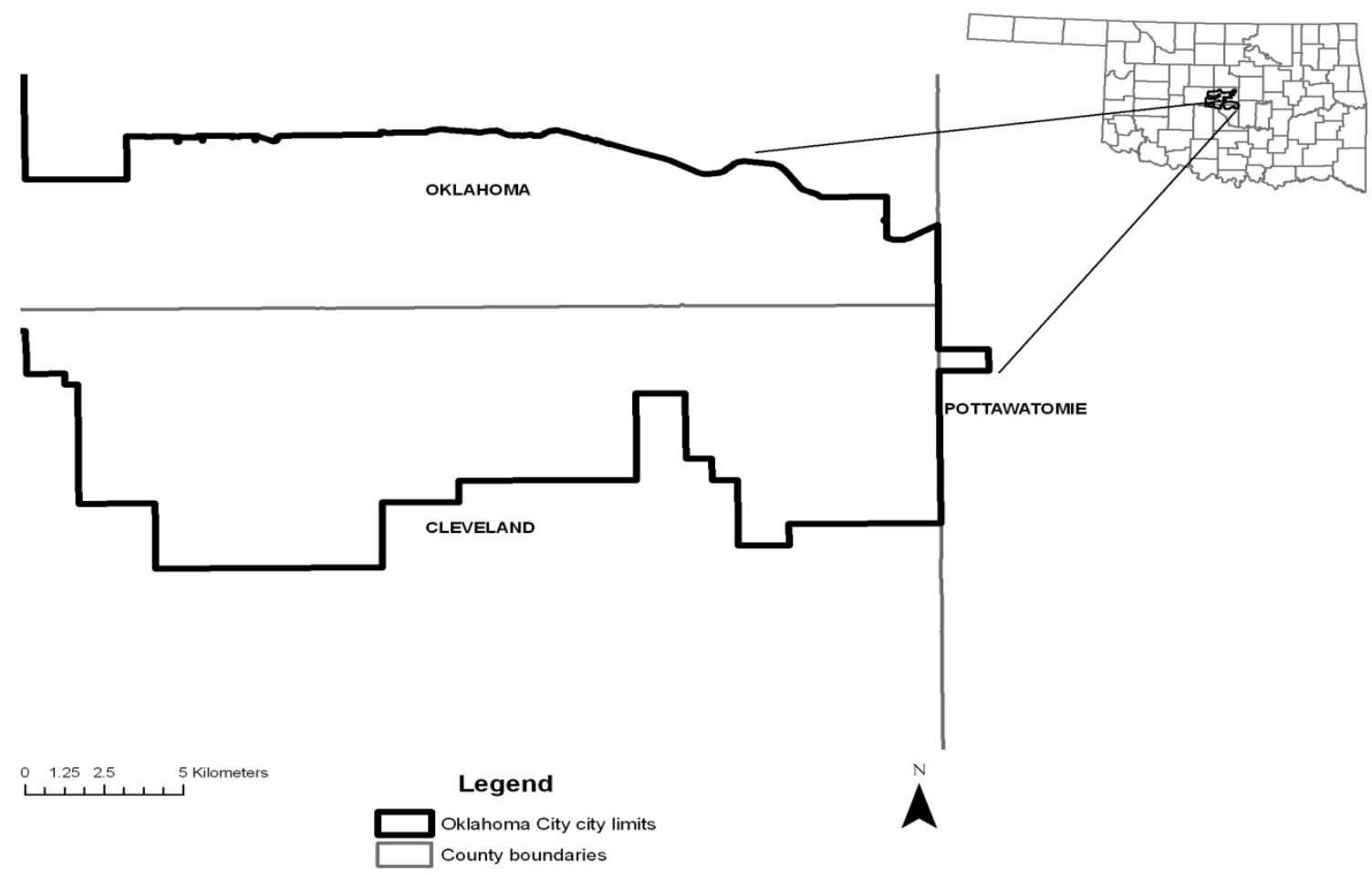

Figure 2 Study area - southeastern Oklahoma City.

\section{METHODS}

\section{The Public Land Surveys}

The PLS, conducted in the United States beginning with the Land Ordinance of 1785 , subdivided land into square townships six miles on a side, which were further subdivided into thirty-six sections of one square mile (Stewart 1935). Surveyors would travel along the section lines, erecting monuments at the intersections of section lines and making notes about the landscape, soil, and vegetation in order to draw an accurate plat of the township following the survey (Bourdo 1956). Surveyors were also instructed to list tree species encountered in

Thomas, R. E. \& Hoagland, B. W. 
order of predominance at the end of each section line, known as "ranked timber observations" (Bourdo 1956, Grimm 1981).

In order to facilitate the relocation of a section corner, at the intersection of section lines the surveyors would record the distance, direction, species, and diameter of four near and "durable" trees. One tree was recorded in each quadrant formed by the intersection of the section lines (Grimm 1981). These were known as bearing trees and were inscribed by the surveyors. Two trees were also marked as bearing trees at the half-mile interval between the intersections of section lines (Bourdo 1956, Fagin and Hoagland 2002, Figure 3).

Since the 1873 bearing tree data was not taken in individual plots, relative frequency (RF) was not calculated, and relative basal area (RBA) and relative density (RD) were combined to provide an importance value (IV).

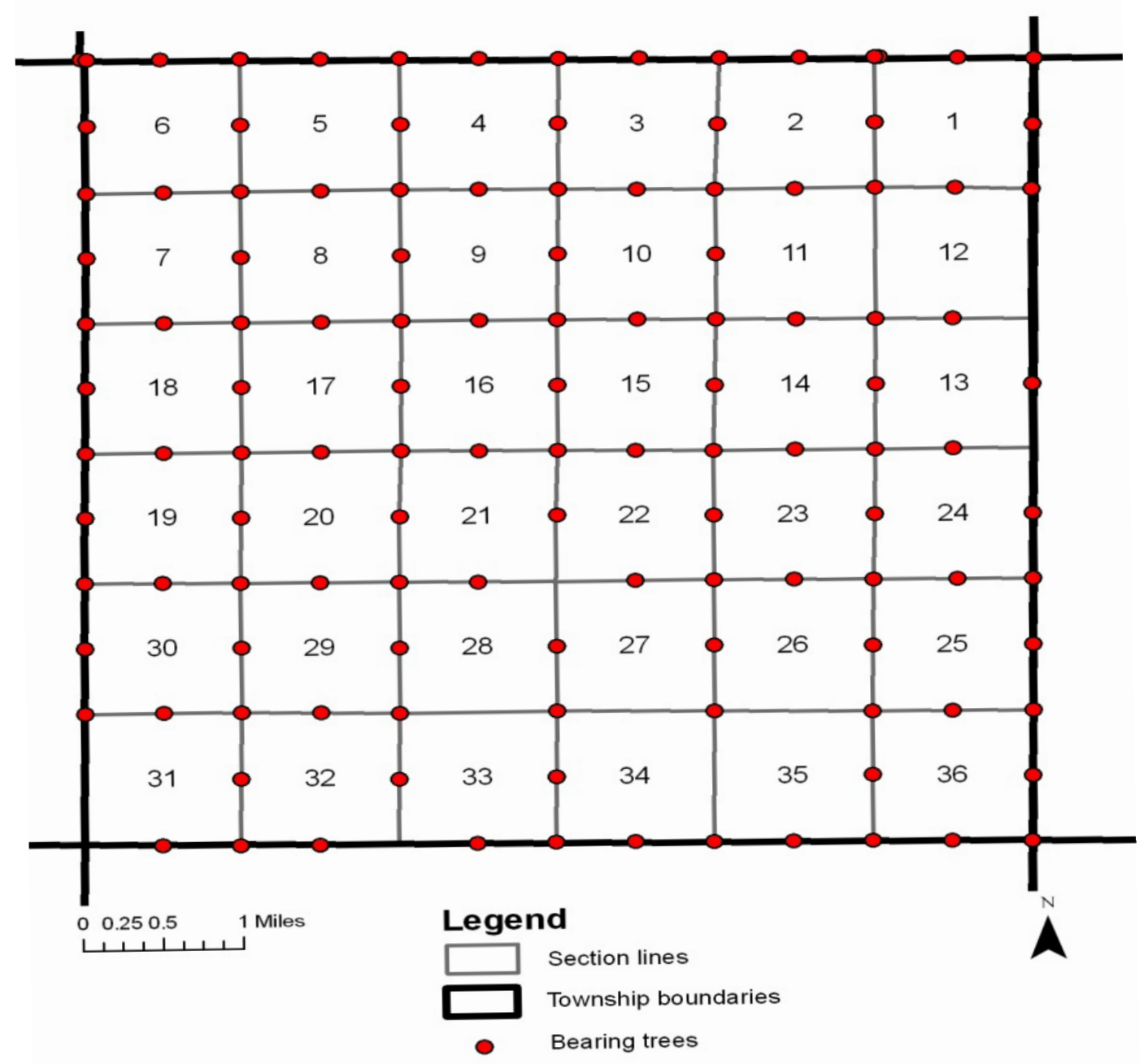

Figure 3 Bearing trees noted at the intersection of section lines and at halfway points along the section lines. 


\section{Contemporary vegetation}

The first stage of analysis was the interpretation and delineation of forest vegetation in the study area using four Digital Orthoquarter Quads (DOQQs) from June 2006. Each DOQQ was imported into Arcmap GIS and joined into a complete coverage. The resulting layer was reviewed and forest vegetation delineated, resulting in a map of either "potential" or "probable" undisturbed Cross Timbers.

Ground-verification of the preliminary map began in the winter of 2007 and consisted of two phases. First, sites were visited to determine the accuracy of the initial disturbance designations of potential or probable. Sites that were verified as or upgraded to probable were then considered for the collection of quantitative vegetation data pending contact with and approval of the landowner. Following the verification of the accuracy of these designations, field studies commenced in order to characterize the structure and species composition of forest/woodland vegetation at these sites, using twenty-by-twenty meter plots. Where possible, multiple plots were established at a site. However, collection of quantitative data even at "probable" sites was somewhat limited by low quality of vegetation and access restrictions. Each tree and shrub was identified to species (nomenclature follows the US Department of Agriculture-Natural Resources Conservation Service [USDANRCS 2006]) and stems exceeding $7.5 \mathrm{~cm}$ diameter-at-breast-height (DBH) were measured within plots, so that this data could be compared to the PLS bearing tree data, as few trees below this size were marked by GLO surveyors. Basal area (BA) was calculated for each species in each plot using the formula Area $=\Pi r^{2}$. Relative Basal Area (RBA) was calculated as:

$$
\left(\sum \mathrm{BA}_{\text {species I }} / \sum \mathrm{BA}_{\text {all species }}\right) \mathrm{X} 100=\mathrm{RBA}
$$

Density (D) was defined as the number of stems for each species occurring in a plot. Relative density (RD) was calculated as:

$\left(\sum \mathrm{D}_{\text {species } \mathrm{I}} / \sum \mathrm{D}_{\text {all species }}\right) \mathrm{X} 100=\mathrm{RD}$

Frequency was defined as the number plots in which a species occurred. Relative Frequency (RF) as calculated as:

$\left(\sum \mathrm{FREQ}_{\text {species I }} / \sum \mathrm{FREQ}_{\text {all species }}\right) \mathrm{X} 100=\mathrm{RF}$

An importance value (IV) was calculated for each species in order to determine which trees were stand dominants:

$\mathrm{IV}=\mathrm{RBA}+\mathrm{RD}+\mathrm{RF}$

\section{RESULTS}

\section{Public Land Survey}

A total of 608 trees were recorded by PLS surveyors within the study area. Ten different species were recorded. Of these, 397 individuals were Q. marilandica and 182 were Q. stellata. Fourteen stems of Ulmus sp. were recorded, but no other species was recorded more than three times. $Q$. marilandica had a total basal area of $9.76 \mathrm{~m}^{2}$, Q. stellata $16.37 \mathrm{~m}^{2}$. No other species had a total basal area over $1 \mathrm{~m}^{2}$. The highest importance values for 1873 bearing tree data were scored by Q. marilandica at 100.89 and Q. stellata at 89.65 (Table 1). The importance values of other species marked as bearing trees were very low. Ulmus sp. had an importance value of 3.29, Carya texana 2.87 and Populus deltoides 1.20. Public land surveyors also reported finding Fraxinus nigra (black ash), a species native to northeastern North America and not found in Oklahoma. It is likely that different common names applied to species at the time resulted in this anomaly. 


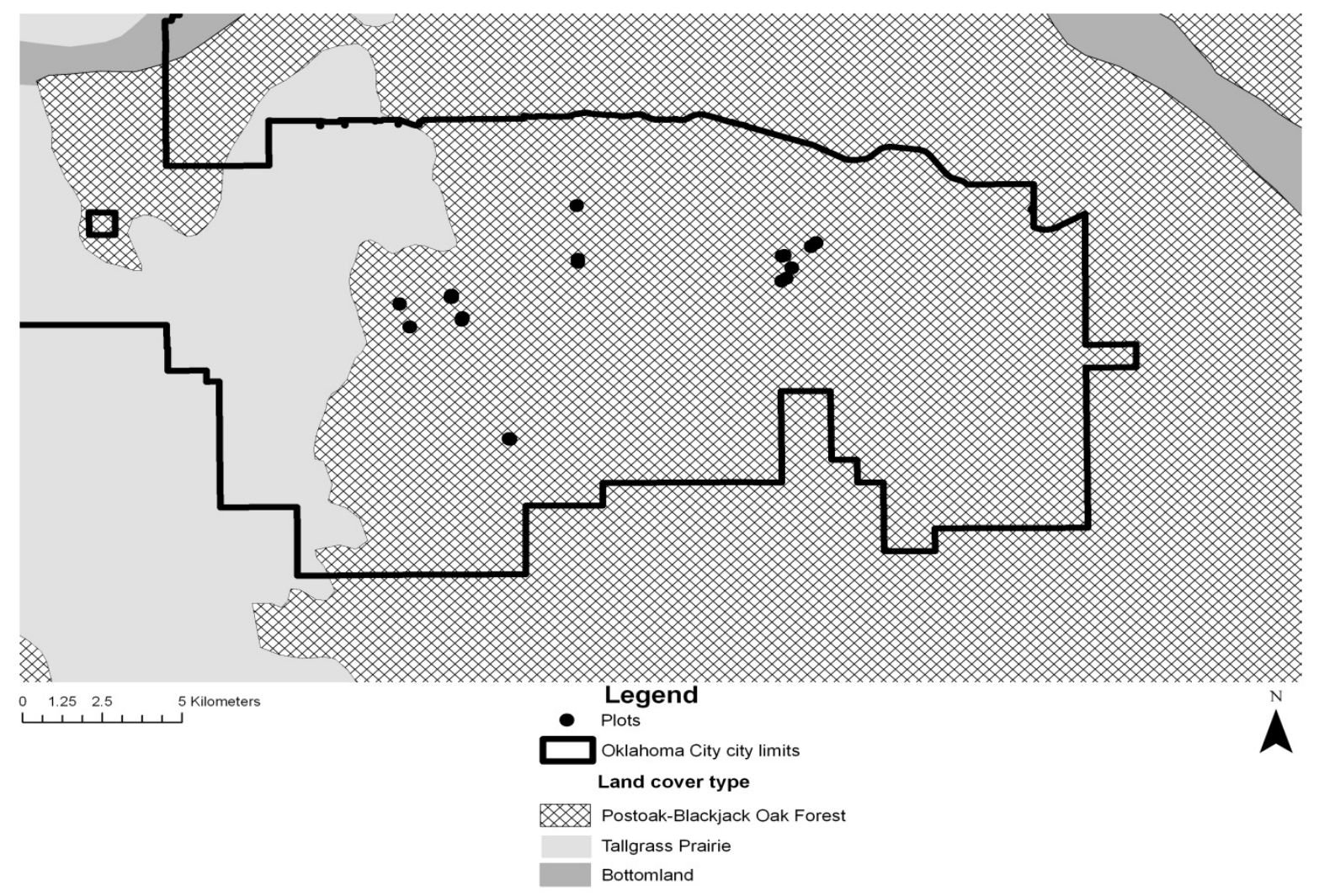

Figure 4 Locations of vegetation plots on sites within the study area.

\section{Contemporary Vegetation}

Vegetation was quantified using a total of twenty-two plots (some in close proximity) on about ten sites (Figure 4). A total of 944 stems with a diameter of at least $7.5 \mathrm{~cm}$ were sampled. Stem diameters ranged from the minimum of $7.5 \mathrm{~cm}$ to 55.5 $\mathrm{cm}$, with a mean diameter of $15.21 \mathrm{~cm}$ and a median diameter of $13 \mathrm{~cm}$. Eighteen woody plant species were encountered (Table 2). The most common were Quercus marilandica (blackjack oak), Quercus stellata (post oak), Carya texana (black hickory), and Juniperus virginiana (eastern redcedar), respectively. Four hundred and two stems of $Q$. marilandica were recorded, ranging in diameter from $7.5 \mathrm{~cm}$ to $42 \mathrm{~cm}$, with a mean diameter of $14.3 \mathrm{~cm}$ and a median diameter of $13 \mathrm{~cm}$. Three hundred ninety-four stems of Q. stellata were recorded, ranging in diameter from $7.5 \mathrm{~cm}$ to $55.5 \mathrm{~cm}$, with a mean diameter of $16.49 \mathrm{~cm}$ and a median diameter of $14.5 \mathrm{~cm}$. Forty-two stems of $C$. texana were recorded, ranging in diameter from $7.5 \mathrm{~cm}$ to $44 \mathrm{~cm}$, with a mean diameter of $17.55 \mathrm{~cm}$ and a median diameter of 16.25 $\mathrm{cm}$. Twenty-four stems of J. virginiana were recorded, ranging in diameter from $7.5 \mathrm{~cm}$ to $22 \mathrm{~cm}$, with a mean diameter of $12.46 \mathrm{~cm}$ and a median diameter of $12 \mathrm{~cm}$.

The highest importance values were scored by $Q$. stellata at 115.26 and Q. marilandica at 96.33 (see Table 2).

C. texana at 20.12 and J. virginiana at 14.49 fell far below these two dominant oaks. Other notable species include Ulmus rubra (Slippery elm) at 9.45 and Celtis occidentalis (common hackberry) at 6.31 .

Plot total basal area values ranged from $0.66 \mathrm{~m}^{2}$ to $1.88 \mathrm{~m}^{2}$ (mean $0.95 \mathrm{~m}^{2}$, median $0.88 \mathrm{~m}^{2}$, standard deviation $0.28 \mathrm{~m}^{2}$ ). The highest basal area values were reported for trees dominant in the Cross Timbers in the following order: Q. stellata $>$ Q. marilandica $>$ 
C. texana. Q. stellata had the highest frequency (22), followed by Q. marilandica (19), J. virginiana (10), and C. texana (9) (see Table 2). Mean basal area for Q. stellata was $0.506 \mathrm{~m}^{2} /$ plot, median basal area 0.38 $\mathrm{m}^{2} /$ plot (range $=0.057 \mathrm{~m}^{2}$ to $1.876 \mathrm{~m}^{2}$, standard deviation $0.474 \mathrm{~m}^{2}$ ), mean basal area for Q. marilandica was $0.343 \mathrm{~m}^{2} /$ plot, median basal area $0.305 \mathrm{~m}^{2} /$ plot (range 0.0 $\mathrm{m}^{2}$ to $0.765 \mathrm{~m}^{2}$, standard deviation 0.252 $\mathrm{m}^{2}$ ), mean basal area for $C$. texana was 0.064 $\mathrm{m}^{2} /$ plot, median basal area $0.0 \mathrm{~m}^{2} /$ plot (range $0.0 \mathrm{~m}^{2}$ to $0.506 \mathrm{~m}^{2}$, standard deviation $0.168 \mathrm{~m}^{2}$ ), and median basal area for J. virginiana was $0.017 \mathrm{~m}^{2} /$ plot, median basal area $0.004 \mathrm{~m}^{2} /$ plot (range $0.0 \mathrm{~m}^{2}$ to $0.133 \mathrm{~m}^{2}$, standard deviation $0.038 \mathrm{~m}^{2}$ ).

Plot density values ranged from 20 to 65 (mean $=42.91$, median $=43$, standard deviation $=15.16)$. The highest density values were for $Q$. marilandica with 21.16 stems/plot (range 0 to 56, median 25, standard deviation 16.3), Q. stellata with 17.91 stems/plot (range 1 to 56, median 17.5, standard deviation 17.16), C. texana with 4.67 stems/plot (range 0 to 13 , median 0 , standard deviation 3.84), and J. virginiana with 2.4 stems/plot (range 0 to 11 , median 1 , standard deviation 3.10).

Table 1 Species scores for bearing trees that fell within the boundaries of the study area from the 1873 PLS data. DEN = total number of stems, BA = total basal area in study area $\left(\mathrm{m}^{2}\right)$, $\mathrm{RD}=$ relative density, $\mathrm{RBA}=$ relative basal area, and $\mathrm{IV}=$ importance value .

\begin{tabular}{|c|c|c|c|c|c|}
\hline 1873 Bearing trees & DEN & $\mathrm{BA}\left(\mathrm{m}^{2}\right)$ & RD & RBA & IV \\
\hline Quercus marilandica & 397 & 9.76171 & 65.29605 & 35.59868 & 100.8947 \\
\hline Quercus stellata & 182 & 16.3742 & 29.93421 & 59.71289 & 89.6471 \\
\hline Ulmus sp. & 14 & 0.270201 & 2.302632 & 0.98536 & 3.287992 \\
\hline Carya texana & 2 & 0.697738 & 0.328947 & 2.544488 & 2.873435 \\
\hline Populous deltoides & 3 & 0.194575 & 0.493421 & 0.70957 & 1.202991 \\
\hline Salix sp. & 3 & 0.04915 & 0.493421 & 0.179239 & 0.67266 \\
\hline Juglans nigra & 3 & 0.020775 & 0.493421 & 0.075762 & 0.569183 \\
\hline Fraxinus nigra & 2 & 0.016214 & 0.328947 & 0.059129 & 0.388076 \\
\hline Celtis occidentalis & 1 & 0.032429 & 0.164474 & 0.118261 & 0.282735 \\
\hline Cercis canadensis & 1 & 0.00456 & 0.164474 & 0.016629 & 0.181103 \\
\hline
\end{tabular}

Thomas, R. E. \& Hoagland, B. W. 
Table 2 Species scores for woody plants in the twenty-two plots sampled. FRQ $=$ frequency, $\mathrm{RF}=$ relative frequency, $\mathrm{BA}=$ total basal area in study area $\left(\mathrm{m}^{2}\right)$, MPLT $=$ median basal area $/ \mathrm{plot}\left(\mathrm{m}^{2}\right), \mathrm{RBA}=$ relative basal area, DEN $=$ total number of stems, MSTM $=$ average density/plot, $\mathrm{RD}=$ relative density, and $\mathrm{IV}=$ importance value.

\begin{tabular}{|c|c|c|c|c|c|c|c|c|c|}
\hline Species & FRQ & RF & BA & MPLT & RBA & DEN & MSTM & RD & IV \\
\hline Quercus stellata & 22 & 22.92 & 10.6 & 0.481 & 50.61 & 394 & 17.91 & 41.74 & 115.26 \\
\hline Quercus marilandica & 19 & 19.8 & 7.112 & 0.374 & 33.95 & 402 & 21.16 & 42.58 & 96.33 \\
\hline Carya texana & 9 & 9.38 & 1.319 & 0.147 & 6.3 & 42 & 4.67 & 4.45 & 20.12 \\
\hline Juniperus virginiana & 10 & 10.42 & 0.321 & 0.032 & 1.53 & 24 & 2.4 & 2.54 & 14.49 \\
\hline Ulmus rubra & 5 & 5.21 & 0.445 & 0.089 & 2.12 & 20 & 4 & 2.12 & 9.45 \\
\hline Celtis occidentalis & 4 & 4.17 & 0.183 & 0.046 & 0.87 & 12 & 3 & 1.27 & 6.31 \\
\hline Quercus muhlenbergii & 3 & 3.13 & 0.202 & 0.067 & 0.96 & 14 & 4.67 & 1.48 & 5.57 \\
\hline Morus alba & 4 & 4.17 & 0.173 & 0.043 & 0.83 & 4 & 1 & 0.42 & 5.42 \\
\hline Carya illinoinensis & 3 & 3.13 & 0.196 & 0.065 & 0.94 & 4 & 1.33 & 0.42 & 4.48 \\
\hline Prunus mexicana & 3 & 3.13 & 0.101 & 0.034 & 0.48 & 4 & 1.33 & 0.42 & 4.03 \\
\hline Cercis canadensis & 3 & 3.13 & 0.033 & 0.011 & 0.16 & 5 & 1.67 & 0.53 & 3.81 \\
\hline Viburnum rufidulum & 3 & 3.13 & 0.051 & 0.017 & 0.24 & 3 & 1 & 0.32 & 3.69 \\
\hline Morus rubra & 2 & 2.08 & 0.102 & 0.051 & 0.49 & 7 & 3.5 & 0.74 & 3.31 \\
\hline Prunus angustifolia & 2 & 2.08 & 0.052 & 0.026 & 0.25 & 5 & 2.5 & 0.53 & 2.86 \\
\hline Celtis laevigata & 1 & 1.04 & 0.028 & 0.028 & 0.13 & 1 & 1 & 0.11 & 1.28 \\
\hline Sideroxylon lanuginosum & 1 & 1.04 & 0.013 & 0.013 & 0.06 & 1 & 1 & 0.11 & 1.21 \\
\hline Quercus macrocarpa & 1 & 1.04 & 0.01 & 0.01 & 0.05 & 1 & 1 & 0.11 & 1.19 \\
\hline Diospyros virginiana & 1 & 1.04 & 0.005 & 0.005 & 0.02 & 1 & 1 & 0.11 & 1.17 \\
\hline
\end{tabular}

Thomas, R. E. \& Hoagland, B.W. 


\section{DISCUSSION}

Two previous studies that have utilized PLS bearing tree data from the Cross Timbers of central Oklahoma provide apt comparison here. Shutler and Hoagland (2004) reported that PLS surveyors sampled 6886 stems in Carter County in the early 1870s, with Quercus stellata (2,648 stems) and Quercus velutina (1,740 stems) being the two most abundant species by far, and only 18 stems of Quercus marilandica recorded. Fagin (2009) reported that PLS surveyors sampled 2,578 trees in the Arbuckle Mountains of south-central Oklahoma in the early 1870s, recording 1,234 stems of $Q$. stellata and 529 stems of $Q$. velutina. These reports would indicate that the composition of Cross Timbers forests in central Oklahoma were drastically different than they are today. However, Thomas (2010) demonstrated that the stems labeled as "black oak" by the PLS surveyors and assumed to be Q. velutina in these studies were almost certainly $Q$. marilandica. "Black oak" was another common name for blackjack oak, and references to $Q$. velutina are almost completely absent from any historical accounts of the Cross Timbers. "Blackjack oak" (Q. marilandica), on the other hand, is almost universally present in these accounts.

Even so, it still appears that in southcentral Oklahoma Q. stellata was twice as abundant as $Q$. marilandica during the first PLS in Oklahoma in the early 1870s. The 2:1 ratio of Q. stellata to Q. marilandica at the time seems to demonstrate that the Cross Timbers of south-central Oklahoma contained more mesophytic vegetation than the Cross Timbers found in Oklahoma and Cleveland counties in central Oklahoma, where a $\sim 1: 2.2$ ratio of $Q$. stellata to $Q$. marilandica was reported by the PLS surveyors in the early 1870s. Carya texana was also much more abundant in southcentral Oklahoma as well, with 118 stems reported by Fagin (2009), but only two recorded by PLS surveyors in Oklahoma and Cleveland counties. This further lends credence to the idea that the Cross Timbers in Carter County and the Arbuckle mountains contained more mesophytic vegetation than those in Cleveland and Oklahoma counties, perhaps as a result of protection from prairie fires, as prairie fires select for fire-tolerant species in environments that would ordinarily trend toward a more mesophytic species composition (Thomas 2010).

In their study of the upland forests of Oklahoma, Rice and Penfound (1959) sampled three sites in Oklahoma County and three sites in Cleveland County (for their sampling methods see Hoagland and Hough 2008). In Oklahoma County they recorded 39 stems of Q. stellata and 137 stems of $Q$. marilandica. In Cleveland County they recorded 66 stems of Q. stellata, 129 stems of $Q$. marilandica, 10 stems of $C$. texana, and 7 stems of Q. velutina (Hoagland and Hough 2008). This $\sim 1: 2.5$ ratio of $Q$. stellata to Q. marilandica is much more in line with the $\sim 1: 2.2$ ratio recorded by PLS surveyors in the early 1870 s than with the $\sim 1: 1$ ratio recorded in the current study.

However, with the reports of $C$. texana and Q. velutina by Rice and Penfound (1955, 1959), we begin to see the results of the "mesophication" of the Cross Timbers noted by this study and by DeSantis et al. (2010). As mentioned in the introduction, this mesophication process is believed to occur as a result of fire exclusion, which "can alter stand structure and create microclimatic conditions that are more beneficial to mesophytic woody species" (DeSantis et al. 2010). In his study, DeSantis (2010) re-sampled 30 forest stands originally sampled by Rice and Penfound (1959) and noted substantial increases in the abundance of C. texana, Juniperus virginiana, and $Q$. stellata, while Q. marilandica declined in abundance. These results are consistent with this study, as we recorded a large increase in C. texana and the fire-intolerant J. virginiana since the 1870s PLS, and the replacement of 
Q. marilandica by the less fire-tolerant $Q$. stellata as the most important species in the Cross Timbers of central Oklahoma.

\section{CONCLUSION}

It is apparent from this study and other studies conducted in the Cross Timbers and in Quercus forests worldwide that the dominance of Quercus, especially those species at the xeric end of the spectrum, is in decline. Fire exclusion seems to be a plausible mechanism, and with the pace of urban, suburban, and ex-urban development the urgency and necessity of fire exclusion will only continue to expand in coverage. Thus, there will likely be nothing to check the mesophication trend in Quercus-forests, save greatly altered land management practices. Noting these trends, future studies might attempt to document what changes in woody species composition mean for other flora and fauna found in Quercus-dominated forests. Documenting changes such as these might increase the urgency for conservation and preservation practices in the Cross Timbers ecoregion.

\section{LITERATURE CITED}

Blinn, W. C. 1958. The Short Grass Plains and Post Oak-Blackjack Woodland of Oklahoma in Historical Perspective. M.S. thesis. Oklahoma State University, Stillwater, $\mathrm{OK}$.

Boren, J. C., D. M. Engle, et al. 1997. Landscape structure and change in a hardwood forest-tall-grass-prairie ecotone. Journal of Range Management 50(3):244-249.

Bourdo, E. A. 1956. A review of the General Land Office survey and of its use in quantitative studies of former forests. Ecology 37(4):754-768.

Briggs, J. M., G. A. Hoch, and L. C. Johnson. 2002. Assessing the rate, mechanisms, and consequences of the conversion of tallgrass prairie toJuniperus virginiana forest. Ecosystems 5(6):578-586.

Brown, A. A. and K. Davis. 1973. Forest Fire Control and Use. $2^{\text {nd }}$ ed. McGraw Hill, New York.

Cooper, M. S. 1998. Riparian Area Management Handbook. Oklahoma Cooperative Extension Service, Division of Agricultural Sciences and Natural Resources, Oklahoma State University and Oklahoma Conservation Commission. E-952.

Coppedge, B. R., D. M. Engle, et al. 2001a. Landscape cover type and pattern dynamics in fragmented southern plains grasslands, USA. Landscape Ecology 16:677-690.

Coppedge, B. R., D. M. Engle, R. E. Masters, and M.S. Gregory. 2001b. Avian response to landscape change in southern Great Plains grasslands. Ecological Applications 11(1):47-59.

Coppedge, B. R., D. M. Engle, R. N. Fuhlendorf, R. N. Chapman, R. E. Masters, and M. S. Gregory. 2002. Juniper encroachment and avifaunal dynamics in southern Great Plains grasslands: A multi-scale summary. Poster paper at the $17^{\text {th }}$ Annual Symposium of the International Association for Landscape EcologyU.S. Regional Association. Lincoln, NE. Coppock, R. K., C. A. Ely, et al. 1955. An evaluation of the quadrat method in the blackjack-post oak forest. Proceedings of the Oklaboma Academy of Science 36:49-50.

DeSantis, R. D., S. W. Hallgren, T. B. Lynch, J. A. Burton, and M. W. Palmer. 2010. Long-term directional changes in upland Quercus forests throughout Oklahoma, USA. Journal of V egetation Science 21:606-615.

Dillard, J., S. Jester, et al. 2006. White-tailed deer food habits and preferences in the Cross Timbers and prairies region of Texas. Texas Parks and Wildlife Department, Austin, TX. PWD RP W7000-1017. 
Dooley, K. 1983. Description and dynamics of some western oak forests in Oklahoma. Ph.D. dissertation. University of Oklahoma, Norman, OK.

Dooley, K. L. and S. L. Collins. 1984. Ordination and classification of western oak forests in Oklahoma. American Journal of Botany 71(9):1221-1227.

Drake B. and P. Todd. 2001. A Strategy for Control and Utilization of Invasive Juniper Species in Oklahoma: Final Report of the "Redcedar Task Force." Oklahoma Department of Agriculture, Food, and Forestry.

Duck, L. G. and J. B. Fletcher. 1945. A Survey of the Game and Furbearing Animals of Oklahoma. Oklahoma Game and Fish Committee Bulletin 144.

Dwyer, D. and P. W. Santelman. 1964. A Comparison of Post Oak-Blackjack Oak Communities on Two Major Soil Types in North-Central Oklahoma. Oklahoma Agricultural Experiment Station, Stillwater, OK.

Dyksterhuis, E. J. 1948. The vegetation of the western Cross Timbers. Ecological Monographs 18(3):325-376.

Dyksterhuis, E. J. 1957. The savannah concept and its use. Ecology 38(3):435442.

Engle, D. M. and J. F. Stritzke. 1992. Vegetation Management in the Cross Timbers. Range Research Highlights 1983-1991, Circular E-905. Cooperative Extension Service, Division of Agricultural Sciences and Natural Resources, Oklahoma State University, Stillwater, OK.

Engle, D. M., T. G. Bidwell, and M. E. Moseley. 1997. Invasion of Oklahoma Rangelands and Forests by Eastern Redcedar and Ashe Juniper. Oklahoma Cooperative Extension Service, Stillwater, OK. Circular E-947.

Fagin, T. 2009. In Search of the Forest Primeval: Data-Driven Approaches to Mapping Historic Vegetation. Ph.D. dissertation. The University of Oklahoma, Norman, OK.
Fagin, T. and B. W. Hoagland. 2002. In search of the forest primeval: The use of land survey records in reconstructing past landscapes and evaluating human impact. The North American Geographer (4):1-20.

Francaviglia, R. V. 2000. The Cast Iron Forest. University of Texas Press, Austin, TX.

Givnish, T. J. 1981. Serotiny, geography, and fire in the pine barrens of New Jersey. Evolution. 35(1):101-123.

Grimm, E. C. 1981. An Ecological and Paleoecological Study of the Big Woods Vegetation in Minnesota. Ph.D. dissertation. University of Minnesota, Minneapolis, MN.

Guthery, F. S. 2001. Green varmints. Quail News. Vol. 1.

Hale, M. 1955. A survey of the upland forests in the Chautauqua Hills, KS. Transactions of the Kansas Academy of Science 58(2):165-168.

Hoagland, B., I. Butler, F. L. Johnson, and S. Glenn. 1999. The Cross Timbers. In: Anderson, R. C., J. S. Fralish, J. M. Baskin, eds. Savannas, Barrens, and Rock Outcrop Plant Communities of North America. Cambridge University Press, New York.

Hoagland, B. W. and D. J. Hough. 2008. Upland Forests of Oklahoma: A Searchable Database of Information from Rice and Penfound (1959). (http://www.biosurvey.ou.edu/rice_and _penfound/index.html), Oklahoma Biological Survey, University of Oklahoma, Norman, OK.

Horncastle, V. J., E. C. Hellgren, P. M. Mayer, A. C. Ganguli, D. M. Engle, and D. M. Leslie. 2005. Implications of invasion by Juniperus virginiana on small mammals in the southern Great Plains. Journal of Mammology 86(6):1144-1155.

Johnson, F. L. and P. G. Risser. 1972. Some vegetation-environment relationships in upland forests of Oklahoma. Journal of Ecology 60(3):655-663. 
Kennedy, R. 1973. An Analysis of Selected Oklahoma Upland Forest Stands Including Both Overstory and Understory Components. Ph.D. dissertation. University of Oklahoma, Norman, OK.

Kowarik, I. 1995. On the role of alien species in urban flora and vegetation. In: Pysek, P, K. Prach, M. Rejmanek, P. M. Wade, eds. Plant Invasions- General Aspects and Special Problems. SPB Academic, Amsterdam, Netherlands.

Kuchler, A. W. 1964. Potential Natural Vegetation of the Coterminous United States. Special Publication Number 36. American Geographical Society, Washington, DC.

Kuchler, A.W. 1974. A new vegetation map of Kansas. Ecology 55:586-604.

Luckhardt, R. and H. Barclay. 1938. A study of the environment and floristic composition of an oak-hickory woodland in northeastern Oklahoma. Proceedings of the Oklahoma Academy of Sciences 18:25-32.

Luniak, M. 1994. The development of bird communities in new housing estates in Warsaw. Memorabilia Zoologica 49:257267.

Marzluff, J. M. 2001. Worldwide urbanization and its effects on birds. In: Marzluff, J. M., R. Bowman, and R. Donnelly, eds. Avian Ecology in an Urbanizing $W$ orld. Kluwer, Norwell, MA.

McKinney, M. L. 2002. Urbanization, biodiversity, and conservation. Bioscience 52(10):883-890.

McKinney, M. L. 2004. Measuring floristic homogenization by non-native plants in North America. Global Ecology and Biogeography 13:47-53.

Mitchell, 2007. Quantitative analysis by the point-centered quarter method. Hobart and William Smith Colleges, Geneva, NY. http://people.hws.edu/mitchell/ PCQM.pdf (retrieved 6/14).

Nowacki, G. J. and M. D. Abrams. The demise of fire and "mesophication" of forests in the eastern United States. Bioscience 58(2):123-138.

Omernik, J. M. 1987. Ecoregions of the conterminous United States. Map (scale 1:7,500,000). Annals of the Association of American Geographers 77(1):118-125.

Penfound, W. T. 1963. The composition of a post oak forest in south-central Oklahoma. The Southwestern Naturalist. 8(2):114-115.

Rice, E. L. and W. T. Penfound. 1959. The upland forests of Oklahoma. Ecology 40(4):593-608.

Rice, E. L. and W. T. Penfound. 1955. An evaluation of the variable-radius and paired-tree methods in the blackjackpost oak forest. Ecology 36(2):315-320.

Schulte, L. A., D. J. Mladenoff, T. R. Crow, L. C. Merrick, and D. T. Cleland. 2007. Homogenization of northern U.S. Great Lakes forests due to land use. Landscape Ecology 22(7):1089-1103.

Shutler, A. and B. W. Hoagland. 2004. Vegetation patterns in Carter County, Oklahoma. 1871. Proceedings of the Oklahoma Academy of Science 84:19-26.

Stewart, L. O. 1935. Public Land Surveys: History, Instructions, Methods. Collegiate Press, Ames, IA.

Strizke, J. F. and T. G. Bidwell. 1989. Eastern Redcedar and its Control. Oklahoma Cooperative Extension Service, Divison of Agricultural Sciences and Natural Resources, Oklahoma State University, Stillwater, OK. Fact Sheet 2850.

Thomas, R. E. 2010. The Cross Timbers in Central Oklahoma Prior to EuroAmerican Settlement: Using the General Land Office Public Land Surveys as a Tool for Vegetation Analysis. M.S. thesis. University of Oklahoma, Norman, OK.

Thurow, T. H. and D. H. Carlson. 1994. Juniper Effects on Rangeland Watersheds. 1994 Juniper Symposium. Texas Agricultural Experimental Station. Tech. Rep. 94-2. 
Vale, T. R. and G. R. Vale. 1976. Suburban bird populations in west-central

California. Journal of Biogeography 3:157-

165.

Thomas, R. E. \& Hoagland, B. W. 